\title{
Constellation Architecture Team-Lunar Scenario 12.0 Habitation Overview
}

\author{
K. J. Kennedy ${ }^{1}$, L. D. Toups ${ }^{2}$, M. Rudisill ${ }^{3}$, LSS Habitat Team ${ }^{4}$ \\ 1 Architect, NASA Johnson Space Center. Mail Code EA3, 2101 NASA Parkway, Houston, TX \\ 77058; PH (281) 483-6629; email: Kriss.J.Kennedy@nasa.gov \\ 2 LSS Habitation Lead, NASA Johnson Space Center. Mail Code ZS; 2101 NASA Parkway, Houston, \\ TX 77058; PH (281) 244-7974; email: larry.toups-1@nasa.gov \\ 3 Space Systems Analyst/LSS Habitation Integration, NASA Langley Research Center. Mail Code \\ 462, Hampton, VA, 23681; PH (757) 864-2317; email: marianne.rudisill-1@nasa.gov
}

\begin{abstract}
This paper will describe an overview of the Constellation Architecture Team Lunar Scenario 12.0 (LS-12) surface habitation approach and concept performed during the study definition. The Lunar Scenario 12 architecture study focused on two primary habitation approaches: a horizontally-oriented habitation module (LS-12.0) and a vertically-oriented habitation module (LS-12.1). This paper will provide an overview of the 12.0 lunar surface campaign, the associated outpost architecture, habitation functionality, concept description, system integration strategy, mass and power resource estimates. The Scenario 12 architecture resulted from combining three previous scenario attributes from Scenario 4 "Optimized Exploration", Scenario 5 "Fission Surface Power System" and Scenario 8 "Initial Extensive Mobility" into Scenario 12 along with an added emphasis on defining the excursion ConOps while the crew is away from the outpost location.

This paper will describe an overview of the CxAT-Lunar Scenario 12.0 habitation concepts and their functionality. The Crew Operations area includes basic crew accommodations such as sleeping, eating, hygiene and stowage. The EVA Operations area includes additional EVA capability beyond the suitlock function such as suit maintenance, spares stowage, and suit stowage. The Logistics Operations area includes the enhanced accommodations for 180 days such as enhanced life support systems hardware, consumable stowage, spares stowage, interconnection to the other habitation elements, a common interface mechanism for future growth, and mating to a pressurized rover or Pressurized Logistics Module (PLM). The Mission \& Science Operations area includes enhanced outpost autonomy such as an IVA glove box, life support, medical operations, and exercise equipment.
\end{abstract}

4 NASA centers participating in CxAT-Lunar Habitat Element Team: JSC, LaRC, KSC, MSFC, JPL, \& GRC. LSS Habitat Management Team: Larry Toups/JSC, LSS Habitation Lead; Kriss Kennedy/JSC; Brand Griffin/MSFC; John Dorsey/LaRC; Dr. Marianne Rudisill/LaRC; Robert Howard/JSC. Habitat Team Leads: Scott Howe, Design; Dr. Robert Howard, Human Systems Integration; Jennifer Green, Supportability Analysis; Kandyce Goodliff, Logistics Resupply; Dr. Jeff Jones, Medical Systems; Robert Trevino, Suitlock, Peggy Guirgis, EVA Systems; Natalie Mary, EVA Systems; Amanda Carpenter, SE\&I; John Dorsey \& Tom Jones, Structures and Mechanisms; John Cornwell, Active Thermal Control; Bob Bagdigian, ECLSS; Oron Schmidt, Avionics; Pat George, PM\&D; Chip Conlee \& Evan Twyford, Internal Architecture, Tracy Gill, Systems Integration. 


\section{Introduction}

The Constellation Architecture Team Lunar Scenario 12.0 surface habitation approach, concept, and assessments performed during the study definition focused on two primary habitation approaches: a horizontally-oriented habitation module (LS12.0) and a vertically-oriented habitation module (LS-12.1). The Lunar Surface Systems (LSS) Habitation Team defined habitation in conjunction with the 12.0 lunar surface campaign, the associated outpost architecture, habitation functionality, concept description, system integration strategy, mass and power resource estimates. The Scenario 12 architecture resulted from combining three previous scenarios after the Lunar Surface Systems (LSS) Project Office architecture review in April 2009. The best attributes from Scenario 4 "Optimized Exploration", Scenario 5 "Fission Surface Power System" and Scenario 8 "Initial Extensive Mobility" were combined into Scenario 12 along with an added emphasis on defining the lunar excursion mission mode. The excursion mode Concept of Operations defined the operational mission of the crew's 14-28 day exploration away from the outpost location, figure 1 .

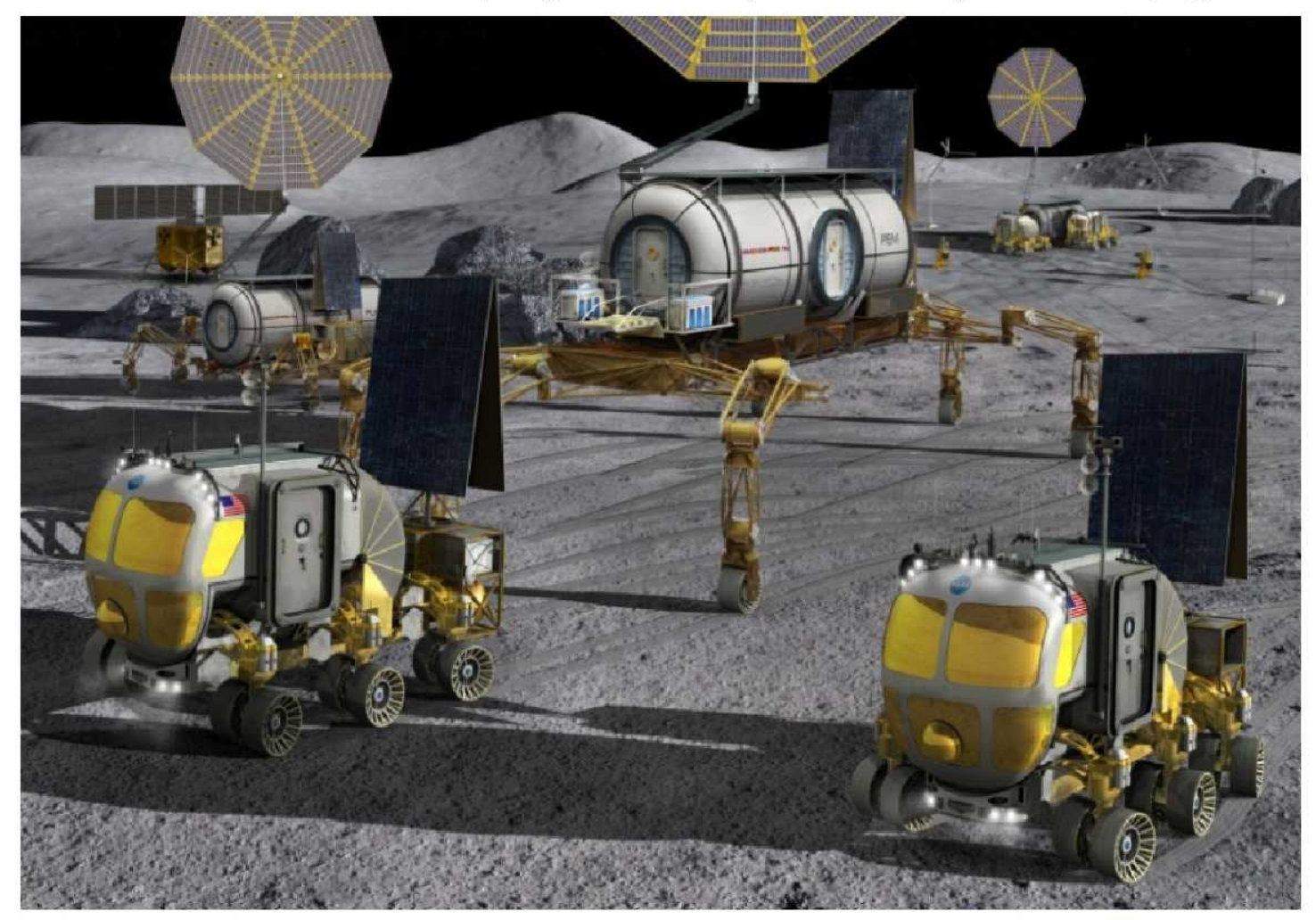

Figure 1, Lunar Scenario 12.0 Pressurized Excursion Module with Rovers

The outpost build-up and end-state integrates design aspects that incorporate supportability. Use of lightweight materials coupled with multi-function structures and packaging reduce the needed mass of systems. Reuse or recycling of elements, systems, components, and basic structural material reduce the need to bring extraneous unused mass to the outpost. All systems are conceptualized with this design philosophy including the Lunar Lander. Reusing the lander offers substantial 
logistics reduction potential if its systems and structure are used as spares and resources for the outpost. Reuse of the lander descent stage is not fully developed and thus is not incorporated into this paper.

The objectives of the Constellation Architecture Team-Lunar habitation studies were to 1) identify promising habitation options that meet the mission architecture objectives, 2) identify desirable habitation features, 3) begin to understand the operational constraints based on different habitation options, and 4) understand the cost and risks of different habitation options. The habitation system is designed to support two mission modes 1) initial habitation mode and 2) outpostcomplete mode with mobile exploration capability.

The lunar poles provide the opportunity to utilize lunar resources that aid in the outpost sustainability and reduce Earth dependant resources. Regolith is a source of potential in-situ resource utilization (ISRU) products including oxygen. Although ISRU production is energy intensive, the greater access to solar power at the poles allows for longer processing times. ISRU production also offers potential access to $\mathrm{H} 2 \mathrm{O}$, hydrogen and other volatiles to increase the ability to "live off the land." ISRU products have potential utility for crew life support, fuel cell replenishment, and propellant production.

The surface human mobility uses the Lunar Electric Rover (LER) concept to support two crew members for nominal exploration operations and four crew members in the event of a contingency, figure 2. The LER is expected to be used extensively on the lunar surface within the first several years of the lunar campaign. The pressurized rover incorporates hatches that will directly interface with the habitat allowing the astronaut to move Intra-Vehicular Activity (IVA) from the pressurized rover to the habitat. The other robotic mobility element is the All-Terrain HexLegged Extra-Terrestrial Explorer (ATHLETE) which is a six-legged robotic vehicle designed to roll over undulating terrain or "walk" over extremely rough terrain. ATHLETE provides mobility to the habitats and serves as a potential alternative platform for the LER.
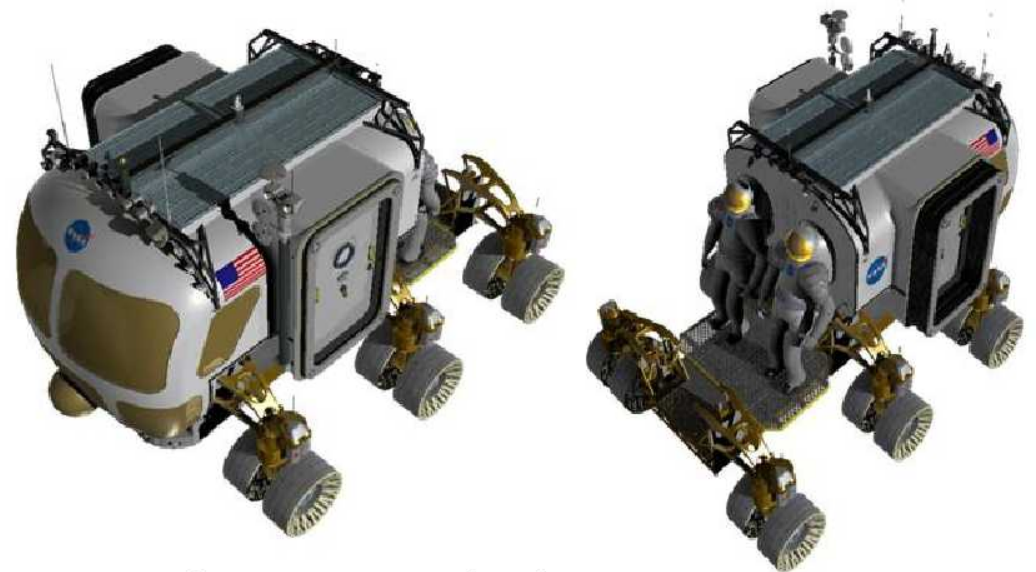

Figure 2, Lunar Electric Rover Concept 
The Power and Support Unit (PSU) consists of a power system integrated with a Structural Support Unit (SSU), figure 3. The SSU is designed to accommodate battery-based or regenerative fuel cell-based systems. The SSU is a frame-truss structure that is designed to incorporate the power system, modular logistics tanks and payloads, communications, and other systems. The SSU is sized to accommodate either a regenerative fuel cell-based or a battery-based power system. It is configurable to integrate with a pressurized module or to operate independently. The SSU provides interfaces to attach payloads for launch, offloading, and transport on the lunar surface. The SSU mates through 12 Lander hard points optimize load distribution of the cargo, figure 4.

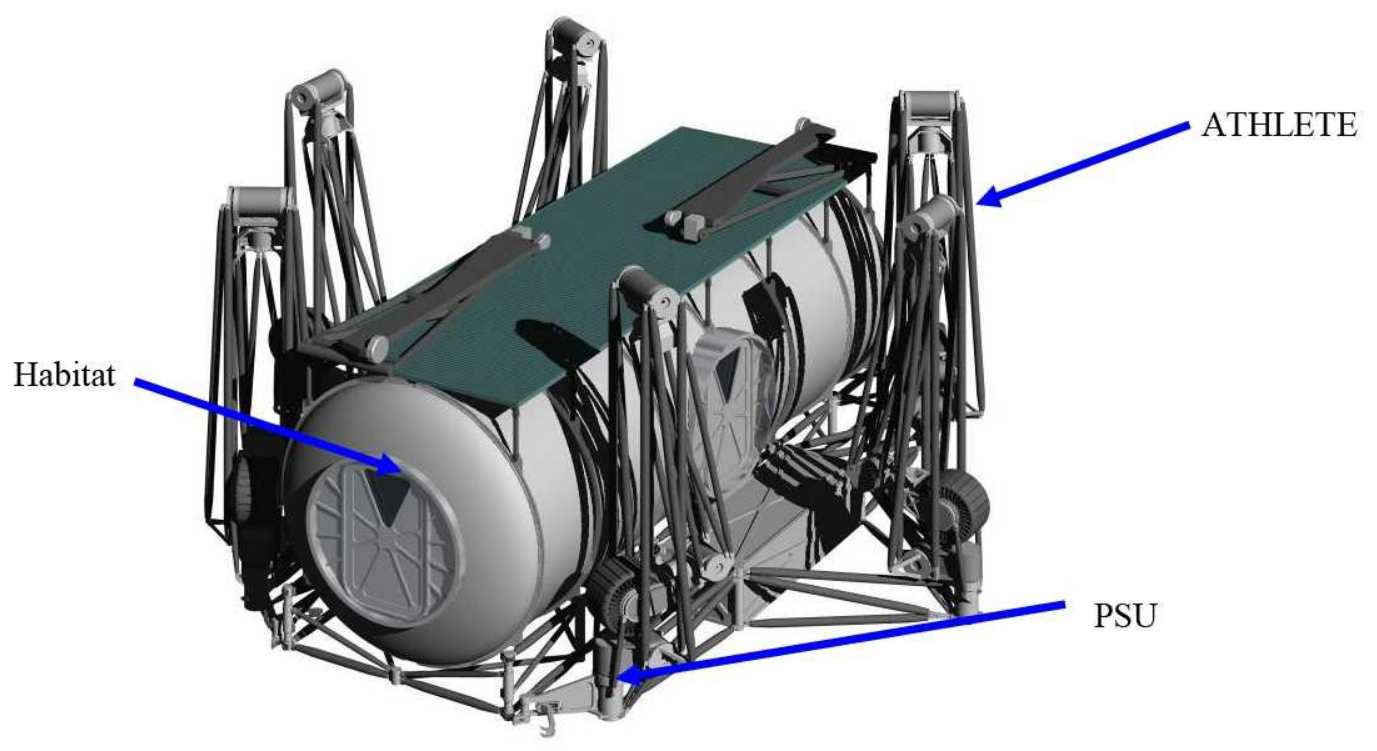

Figure 3, ATHLETE Pre-Integrated to PSU/Habitat

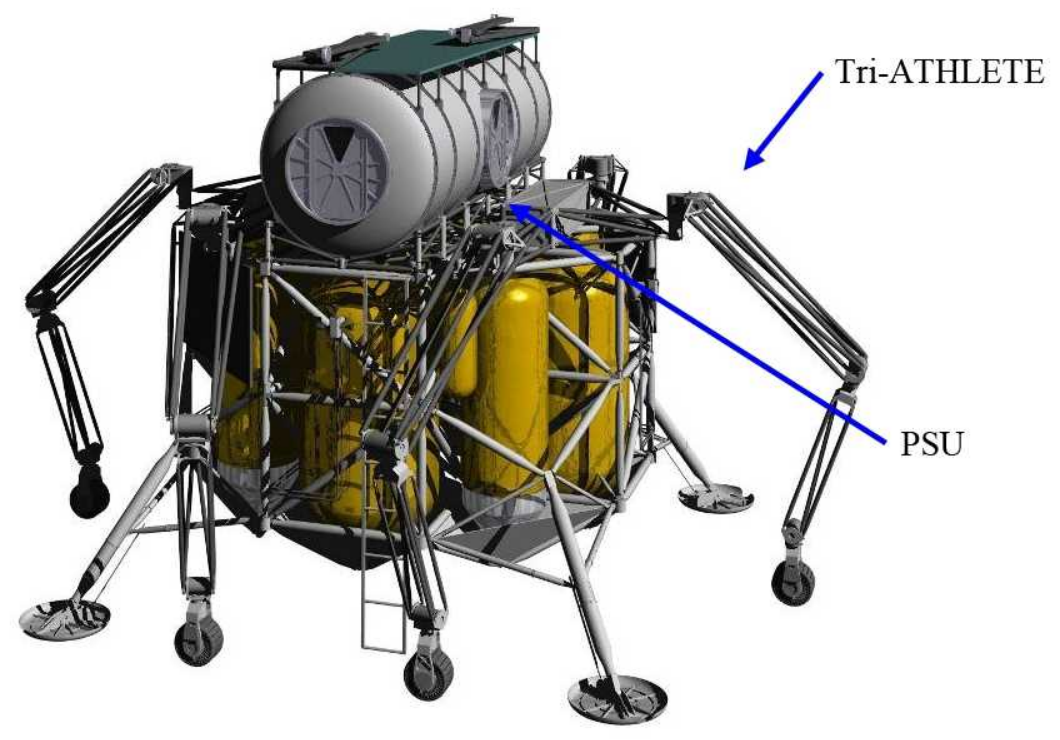

Figure 4, ATHLETE Unloading PSU/Habitat 


\section{Lunar Scenario 12.0 Outpost Configuration}

The lunar scenario 12.0 outpost is comprised of multiple functions and surface elements. Included in the outpost are mobility systems (robotic-ATHLETE and human-LER), habitation systems, communications systems, power systems, ISRU, logistics \& spares, and surface support equipment - such as the Lunar Surface Manipulator System (LSMS), figure 5.

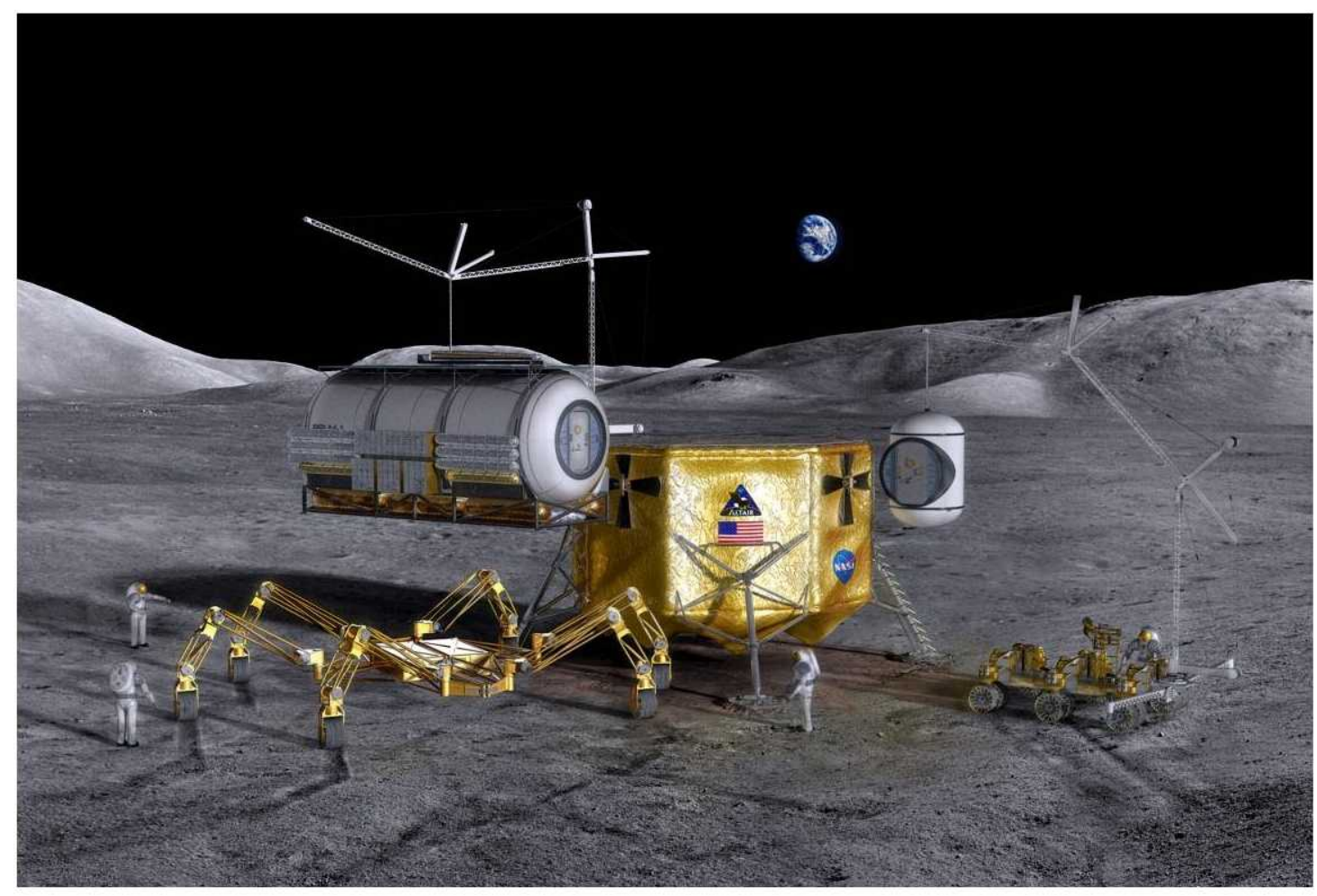

Figure 5, LSMS Unloading a PSU/Habitat

Specific capabilities flow from the mission objectives. The habitation area for the crew will be the core of the surface base. The support of crew and all facilities will require a large power site. If the power generation is using solar arrays then it should be separated from ISRU mining sites to avoid contamination. If using a nuclear system then it can be placed close to the power users. Multiple landings will be required to get equipment to the surface, thus requiring a separate landing/launch sites. The science activities may require a separate site, 'protected' from other surface base activities to ensure pristine environment and research. Typically in-situ resources will be required to sustain an outpost for a long-term campaign.

The outpost notional master plan functionally separates the base into 5 areas of development. Figure 6 shows this functional allocation and interface between areas. A Master Plan is required to strategically plan infrastructure [utilities, site prep, roads, launch \& landing, power generation, ISRU processing location, science observation (undisturbed territory); to assess terrain and environment to take advantage of features and vistas; for site preparation; to place surface assets; and plan growth. Also it is required to plan the lander flight path approach and ascent module 
departure at a safe distance from the outpost. Based on the Plume/Blast Ejecta TIM (KSC, Oct. 2008) results, there is a risk to the surface base outpost assets if Launch and Landing Pads are not built. During the first 7 years there will be approximately 21 landings near the outpost. Including Launch and Landing Pads (figures $7 \& 8$ ) will reduce the risk and increase safety during landings by providing a dedicated landing area [lights, beacons, known target, no dust cloud, recognizable features].

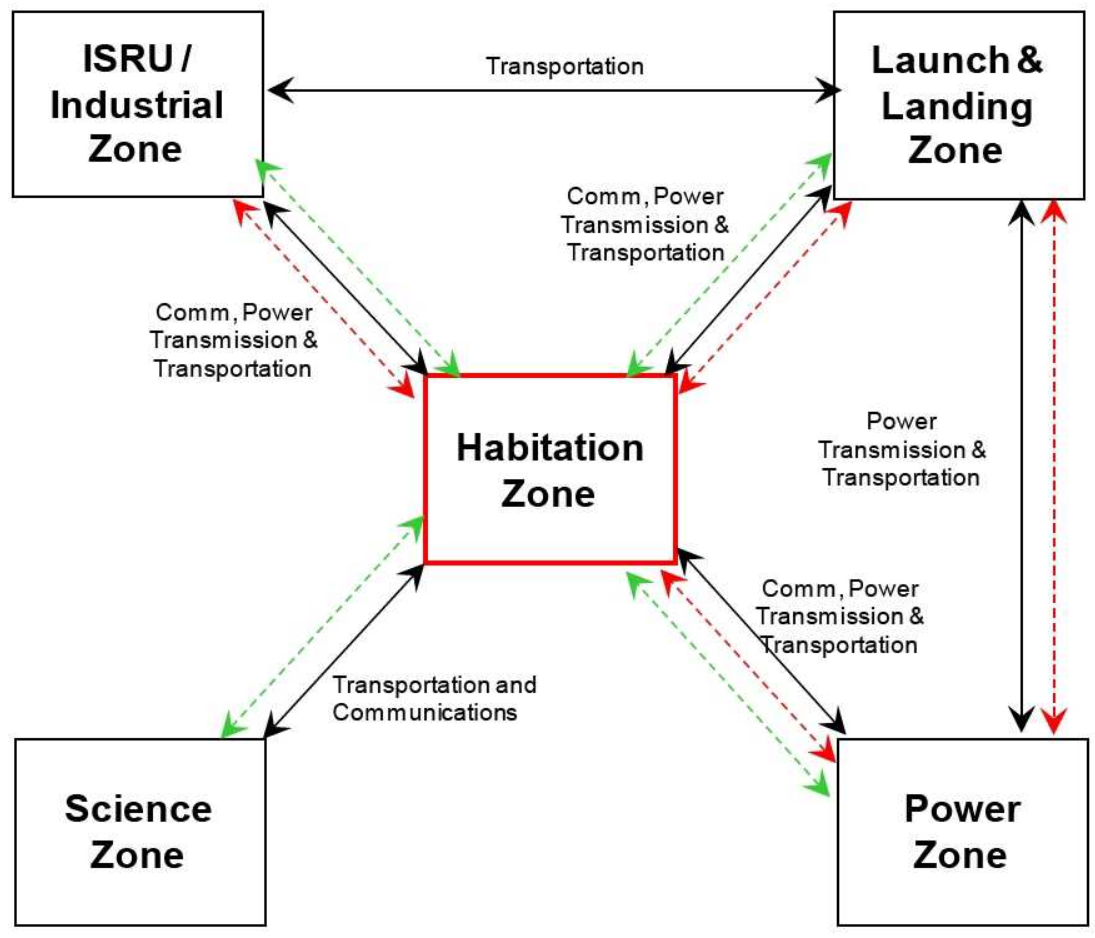

Figure 6, Outpost Master Zoning

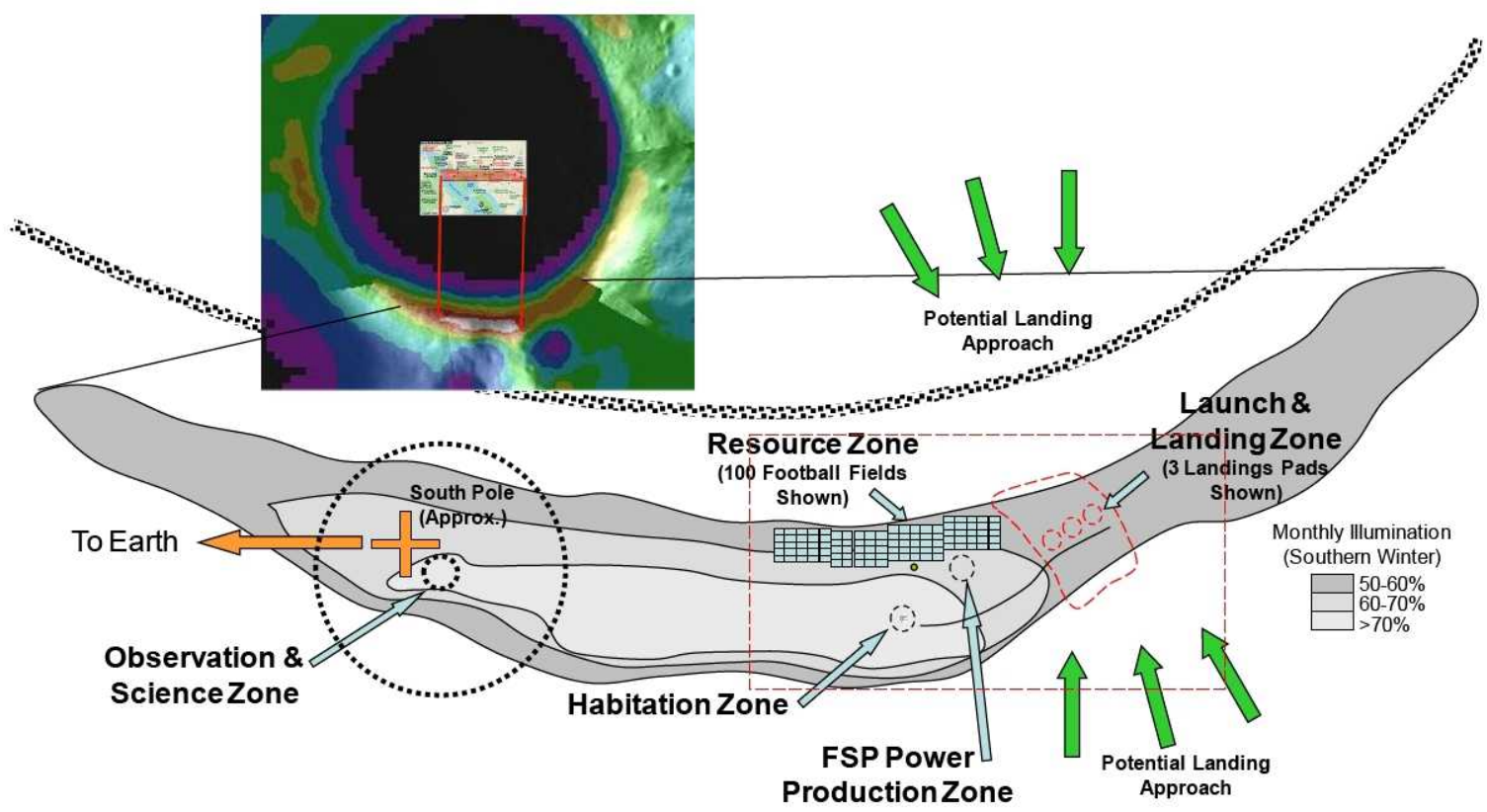

Figure 7, Notional Outpost Master Plan 


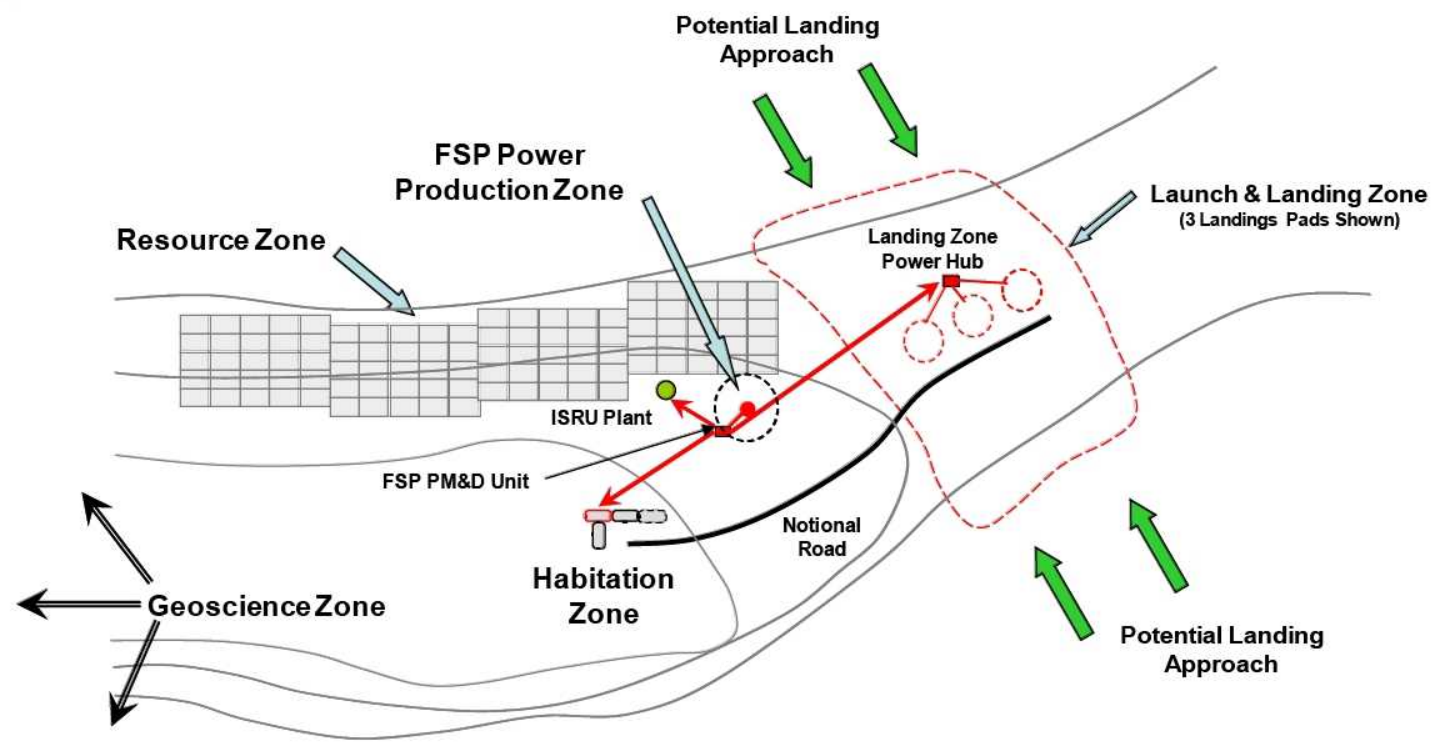

Figure 8, Notional Outpost Master Plan- Closer View

\section{Elements and Operations}

Three major types of pressurized elements can be used as a kit-of-parts to assemble a variety of outpost configurations. The three types of habitat module are Pressurized Core Module (PCM), Pressurized Excursion Module (PEM) (figure 11), and replaceable Pressurized Logistics Modules (PLM). Together with small, highly mobile $\sim 12 \mathrm{~m}^{3}$ pressurized Lunar Electric Rovers (LER) and 3 larger $55 \mathrm{~m}^{3}$ horizontally-oriented cylindrical habitat modules (figure $9 \& 10$ ), they comprise a total outpost pressurized volume of $213 \mathrm{~m}^{3}$, (table 1).

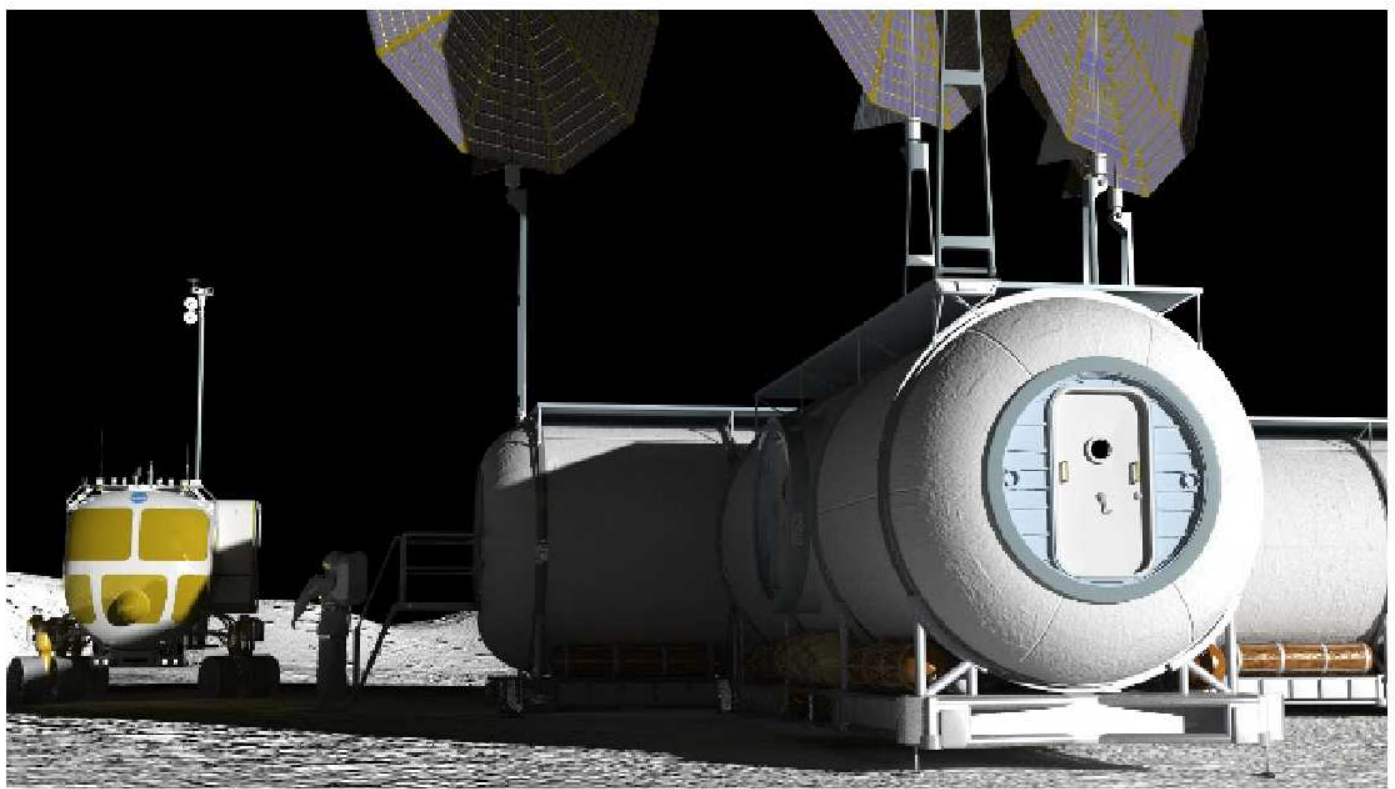

Figure 9, LS-12.0 Outpost External Configuration View (no Protection shown) 


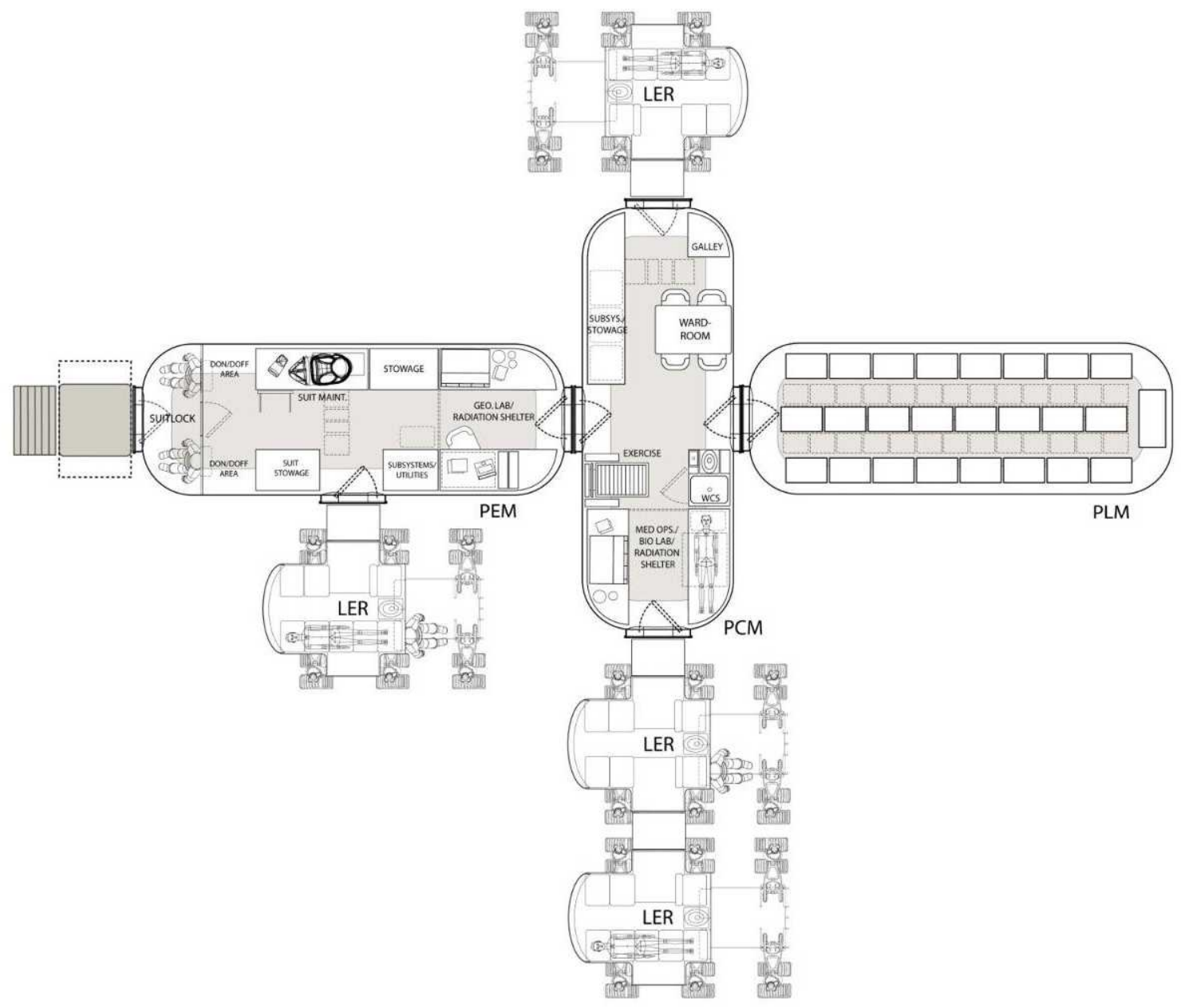

Figure 10, LS-12.0 Outpost Habitation Configuration

Table 1, LS-12.0 Outpost Habitation Pressurized Volume

\begin{tabular}{|r|c|}
\hline Outpost End-State Volume & $\mathbf{~}^{3}$ \\
\hline Pressurized Excursion Module & 55 \\
\hline Pressurized Core Module & 55 \\
\hline Pressurized Logistics Module & 55 \\
\hline LER Pressurized Crew Cabin-1 & 12 \\
\hline LER Pressurized Crew Cabin-2 & 12 \\
\hline LER Pressurized Crew Cabin-3 & 12 \\
\hline LER Pressurized Crew Cabin-4 & 12 \\
\hline total volume & 213 \\
\hline
\end{tabular}

Outpost habitation operations consist of Crew Operations, EVA Operations, Mission Operations, Science Operations, and Logistics \& Supportability Operations. These high-level requirements map to the following primary habitat element functions, interfaces and constraints. 
Crew Operations - IVA: Sustain crew on lunar surface for mission. These functions are necessary to insure the safety of the crew. It also includes providing the functions necessary to sustain the crew from a health and well being perspective. The outpost will enable sustainability of 4 crewmembers on the lunar surface for 7-180 days. These operations will include Intra-vehicular Activity (IVA) sleep, food storage / prep / consumption, personal hygiene, space medicine and health care, adaptation and countermeasures. Each LER can function as private sleeping quarters for the crew, figure 10 .

Crew Operations - Supporting EVA: Enable Redundant EVA Function \& Enhanced EVA Capability. These functions are necessary to provide the crew with additional means to conduct routine EVAs. The extent provided is driven by the mission duration and the number of EVAs required conducting that mission. The outpost will enable redundant EVA functions through suitport, suitlock, and alternate egress systems.

Mission Operations: Enable Enhanced Mission Operations Capability. These functions are those that enable the lunar surface crew to conduct surface operations in concert with the Earth based mission control. For longer surface stays it should also establish autonomy from the Earth based "mission control" enabling command and control with other surface assets such as rovers, landers, etc. The outpost will enable enhanced mission operations capability, structure and environmental protection, power management and distribution, communications, life support, thermal control, lunar surface science and technology demonstrations.

Science Operations: Enable IVA Bio/Life Science \& GeoScience Capability. These functions are necessary to conduct the science involved with the mission. It can include sample collection, sample storage, any analyses required, and any sample return required. It also is meant to include any specific "environmental" requirements specific to Life Science or GeoScience. The outpost will enable enhanced IVA life science, bioscience, and geo-science capability.

Logistics \& Maintenance Operations - IVA \& EVA: Enable Maintenance, Resupply, \& Spares Cache. These functions are those that allows for maintaining the surface assets during recognized maintenance intervals. It also includes those functions necessary to resupply the habitat(s) with consumables (both pressurized and unpressurized) to support the crew for the mission. Lastly, it also includes the functions necessary to deliver and store the necessary spares related to the maintenance as well as unexpected failures. The outpost will enable resupply, stowage / inventory / trash management, and spares cache. Logistics packaging can be converted into internal outfitting, partitions, furniture, and cabinets after initial use, in a 'Logistics-to-Living' approach. 


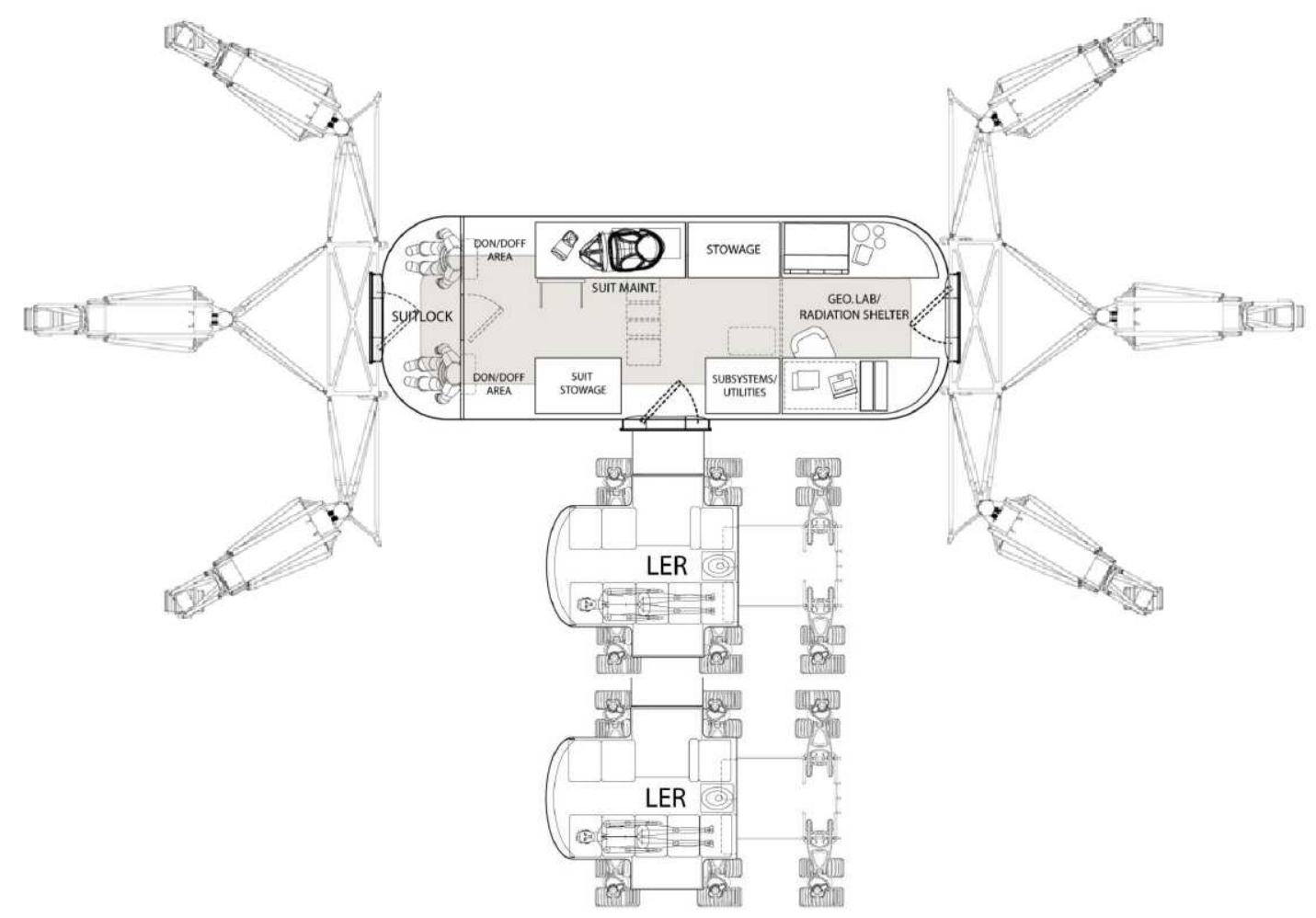

Figure 11, LS-12.0 Exploration/Excursion Mode Configuration

\section{Lunar Scenario 12.0 Habitation}

The habitat elements provide a pressurized environment for the crewmembers to live in and work while performing mission tasks on the lunar surface. There are a number of architecture-level requirements that must be met by the habitat elements: reduce risk, reduce cost, achieve a basic level of crewed lunar surface stays as early as possible, and support outpost operations with a core habitat element while meeting the initial habitation functionality and volume goals.

\section{Primary Functions}

The habitat elements collectively provide adequate volume and protection (radiation and micrometeoroid/secondary ejecta (MM/SE)) within a self-contained pressurized environment for the crew to perform all mission and habitation functions, including: EVA operations (e.g., preparation and post-EVA activities), Logistics \& Supportability operations (including associated maintenance and spares stowage), Science operations, Mission operations, Medical operations, and Crew operations/habitation support (e.g., food preparation, personal hygiene, stowage). During the outpost buildup a dual means for ingress/egress are provided. Each habitat element uses common outpost systems (power, data, fluids, structures, etc.) and has a high-level of commonality in accommodations. A common pressure shell is used for outpost and logistics operations missions. Each habitat element provides at least one pressurized docking interface for the Pressurized Logistics Module (PLM), one pressurized docking interface for the Lunar Exploration Rover (LER), and a 
pressurized interface between habitat elements. All pressurized interfaces may be used simultaneously without interference. The habitat element provides space/volume and utilities for both habitation and laboratory functions within a single pressurized volume. Habitat elements are delivered to the lunar surface on Lander cargo missions. The habitat element is designed to fit within the area and volume afforded by the Lander cargo deck and the launch vehicle shroud. The habitat will provide displays and controls for the management of lunar surface elements. The habitat provides primary command and control of lunar surface elements and lunar surface mission operations. The habitat will provide processing and algorithms for communications, navigation, imaging, and command and data handling. The habitat provides crew IVA communications. The habitat provides monitoring, data handling, storage, and transmission for habitat crew, mission, and science systems.

\section{External Interfaces and Constraints}

An overview of PCM habitat interfaces is shown in figure 12. The habitat elements interact with the Lander, the Power and Support Unit (PSU), the Lunar Electric Rover (LER), and EVA System (EVAS).

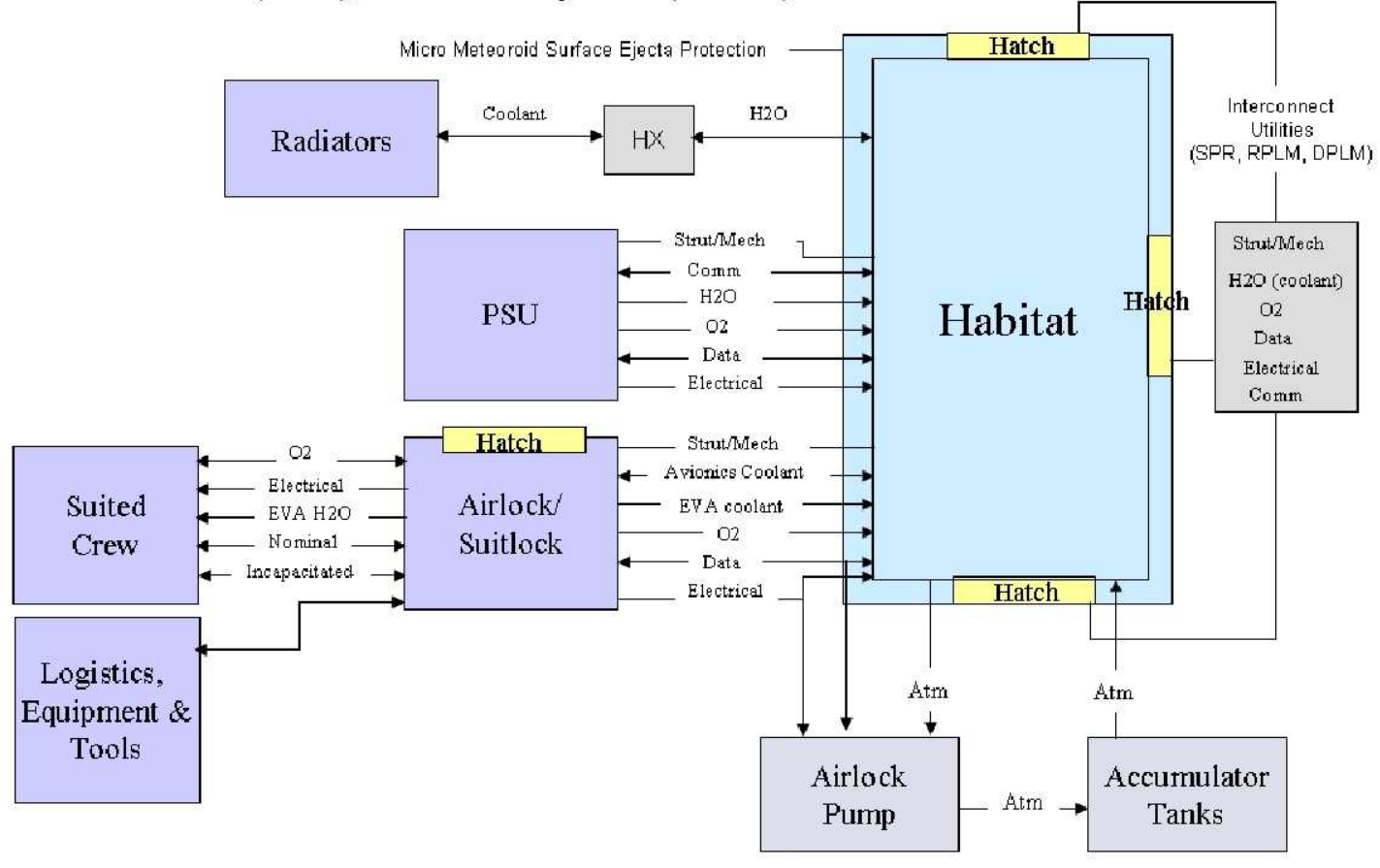

Figure 12, PCM Habitat Interface Diagram

\section{Element Ground Rules and Assumptions}

There are numerous ground rules and assumptions pertaining to the surface habitation. Interior outfitting allows easy customizing and reconfiguring to meet varying outpost functional and contingency needs (e.g., a second habitat element could be retrofitted to accommodate the basic functions of the first element in a contingency situation where the first element becomes non-operational). The habitats are designed with an operational lifetime of 10 years from Outpost Complete. The habitation system assumes that crews of four never overlap on the surface; therefore, 
there is no requirement for the habitation system to support more than a maximum of four crewmembers simultaneously. The habitation system assumes that early lunar outpost missions are of short duration and mission durations gradually increase, eventually reaching a maximum of 180 days at the lunar outpost. Mobile laboratory operations mission durations are TBD.

Mechanisms are provided for coarse and for fine alignment and leveling of the habitat elements to facilitate integration into the outpost on the lunar surface. Coarse alignment is provided by the habitat leveling mechanism system and the PSU selfleveling function and fine alignment between elements is provided by the common Active-Active Mating Adapter. The habitat element accommodates TBD structural loads; the PSU may carry some or all of habitat element loads. Habitat elements survive in standby mode on the Landers for TBD duration after delivery. Habitat elements function in full operational and in quiescent modes on the Landers for TBD duration prior to offloading and emplacement on the lunar surface. The habitation complex accommodates an EVA of up to four crewmembers on the surface simultaneously. Ingress/egress is performed by two crewmembers at a time.

Each habitat element is delivered filled with pressurized logistics. The outpost is re-supplied over its lifetime by use of a PLM. A PLM is delivered on cargo missions with pressurized and unpressurized logistics that vary on a mission-bymission basis. The habitat elements can accommodate a PLM at any point in the assembly sequence buildup. Protection for the crew from radiation, thermal, and $\mathrm{MM} / \mathrm{SE}$ is provided by the habitat elements. Long-term Galactic Cosmic Radiation (GCR) protection is not provided.

The habitat elements can be operated under reduced operations conditions. Applicability to a crewed Mars mission ("Mars Forward") is considered in the lunar habitation system design. The habitat system mission support avionics allow the crew to operate at a high level of autonomy (e.g., crewmembers can make local decisions concerning daily schedules) independent of earth-based Mission Control. The habitat element science functionality allows crew access to, and uncontaminated handling of, lunar surface samples. Common "self-contained/pre-integrated" habitat elements are used for both lunar outpost and logistics operations missions.

\section{Element Description}

A graphical depiction of the PCM Habitat integrated with the PSU is given in Figure 13, the interior plan of the PEM and PCM Habitat is shown in figure 14 and 15 respectively, and a three-dimensional model of the PCM Habitat and initial habitat integrated subsystems are shown in figure 16. The assumed habitat element geometry is:

- The pressurized Habitat element is a $3.0 \mathrm{~m}$ internal diameter $\times 8.35 \mathrm{~m}$ internal length (providing $\sim 55 \mathrm{~m}^{3}$ pressurized volume) aluminum-lithium hard-shell horizontal cylinder. Contained within the PEM Habitat is an airlock/suitlock that provides $\sim 6.5 \mathrm{~m}^{3}$ of volume and accommodates two EVA suits at one time. 
- This outpost configuration (with three horizontal hard shell elements: (PEM, PCM, and PLM) has a total pressurized volume $\sim 165 \mathrm{~m}^{3}$ plus the 4 LERs thus providing $\sim 213 \mathrm{~m}^{3}$. That equates to $53.25 \mathrm{~m}^{3}$ of pressurized volume per crewmember.

- The PCM Habitat element has four ports to allow multi-directional expansion of the outpost while providing two ports open for docking of the pressurized rovers.

- The PEM Habitat element has three ports to allow multi-directional expansion of the outpost while providing two ports open for docking of the pressurized rovers (one port provides crew access to the lunar surface via the suitlock).

- The floor area of each Habitat element is $\sim 2.3 \mathrm{~m} \mathrm{x} \sim 7.75 \mathrm{~m}=\sim 17.83 \mathrm{~m}^{2}$.

- This outpost configuration with three horizontal hard shell elements: (PEM, PCM, and PLM) has $\sim 53.48 \mathrm{~m}^{2}$ total floor area across the three habitat elements.

- The PEM and PCM Habitat elements each provide Solar Proton Event (SPE) protection for four crewmembers via use of a "water wall" system.

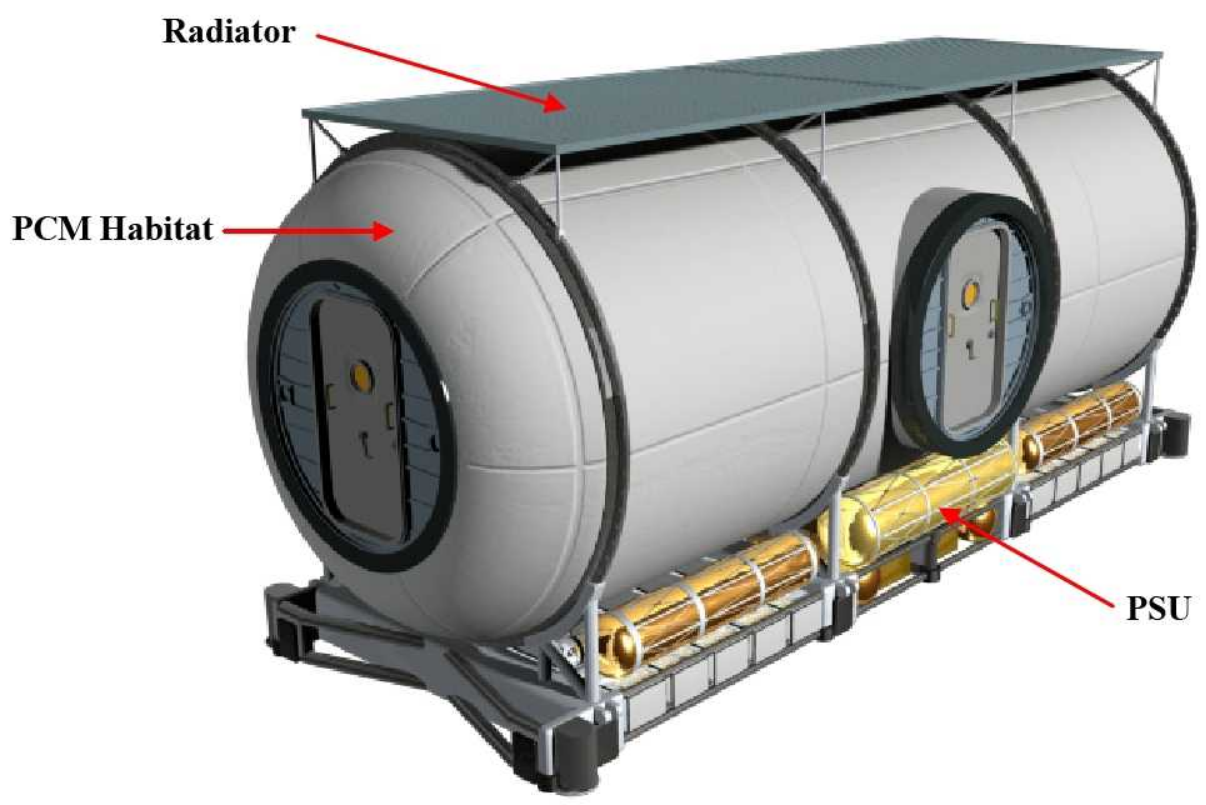

Figure 13, Habitation Element Integrated with PSU 


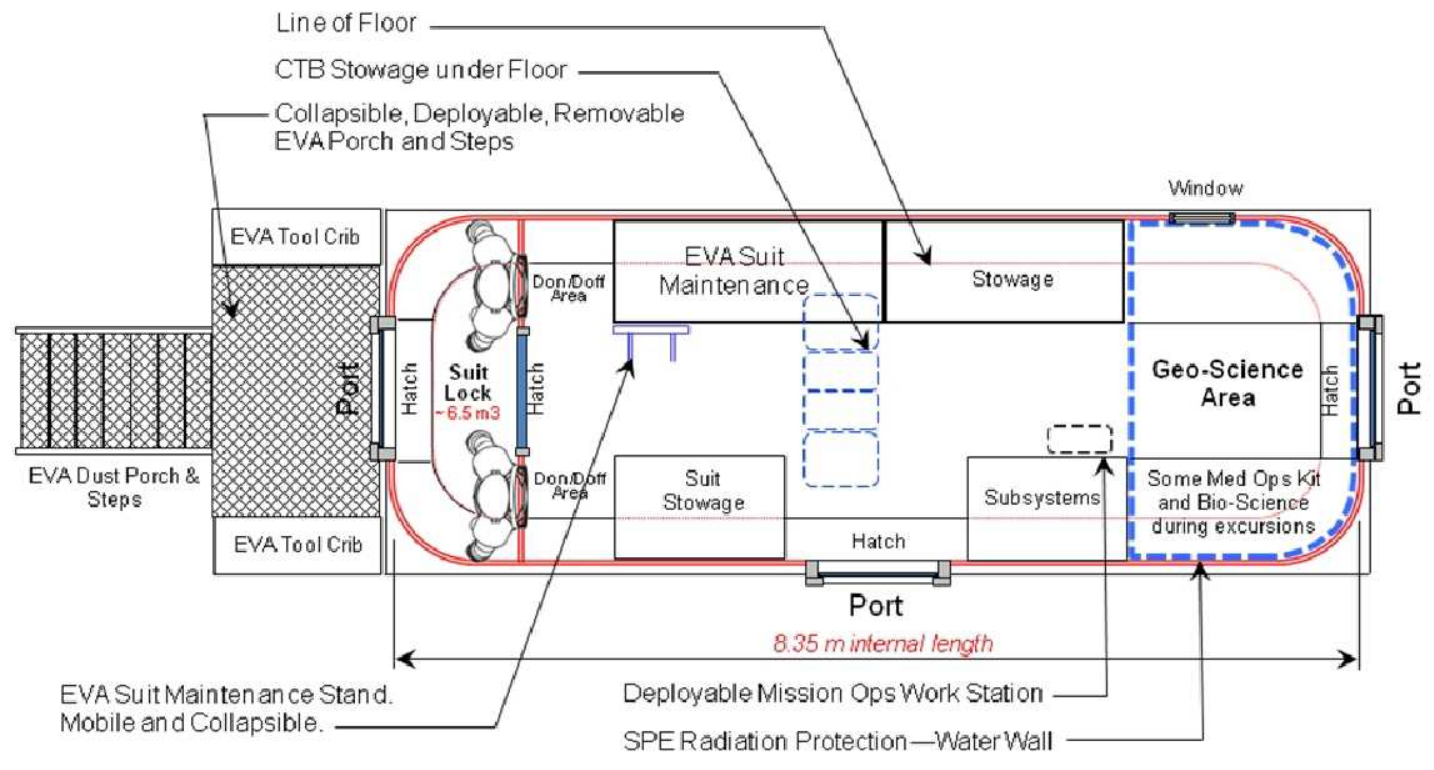

\section{3-Port PEM Plan}

$3.0 \mathrm{~m} \mathrm{ID} \times 8.35 \mathrm{~m} \mathrm{IL}=\sim 55 \mathrm{~m} 3$
Floor Area:

$\sim 2.25 \mathrm{~m} \times 7.75 \mathrm{~m}=17.44 \mathrm{~m} 2$

Figure 14, PEM Habitat Plan View

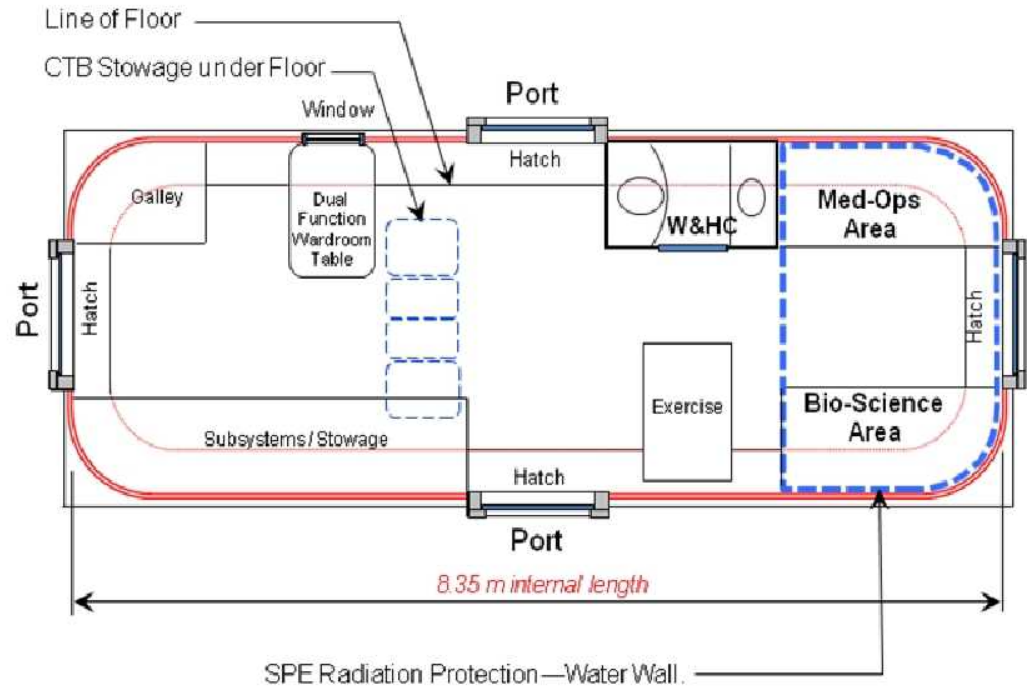

4-Port PCM Plan

$3.0 \mathrm{mID} \times 8.35 \mathrm{mIL}=\sim 55 \mathrm{~m} 3$

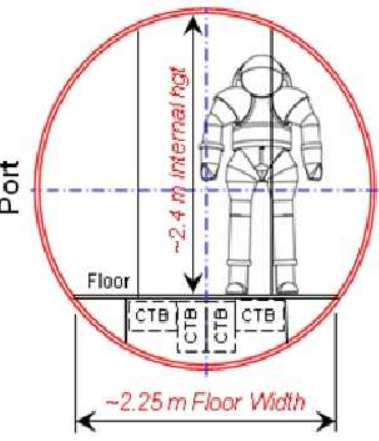

Module Cross Section $3 \mathrm{~m} \mathrm{ID}$

\section{Floor Area:}

$\sim 2.25 \mathrm{~m} \times 7.75 \mathrm{~m}=17.44 \mathrm{~m} 2$

Figure 15, PCM Habitat Plan View 


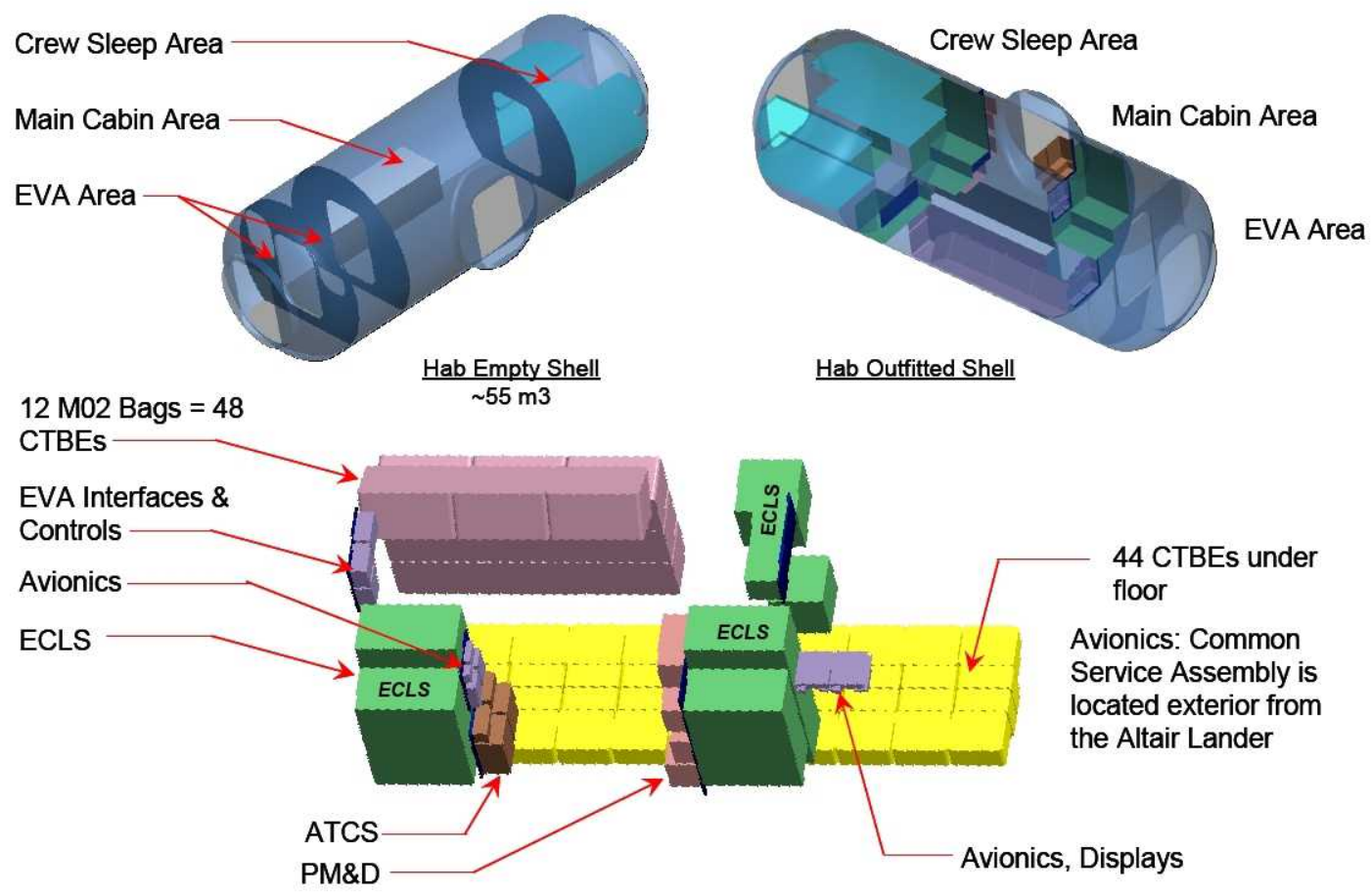

Figure 15, Habitat Element Integrated Subsystems

The PCM Habitat element is supported and powered by an integrated Power and Support Unit (PSU) when deployed to the lunar surface. The PCM Habitat subsystems are sized based on the full-up outpost capability incorporating the outpost expansion (i.e., the PCM Habitat, PEM, and PLM). The PCM Habitat will host all of the primary operating systems; redundancy is provided by the subsystem's designs.

The habitation EVA system has one suitlock (accommodates two suits) in the PEM Habitat, suit maintenance (figure 16), and each LER has two suitports. The PEM also provides a dust containment area which accommodates two suits as well. The second, and redundant, nominal EVA egress/ingress capability is provided by the LERs.
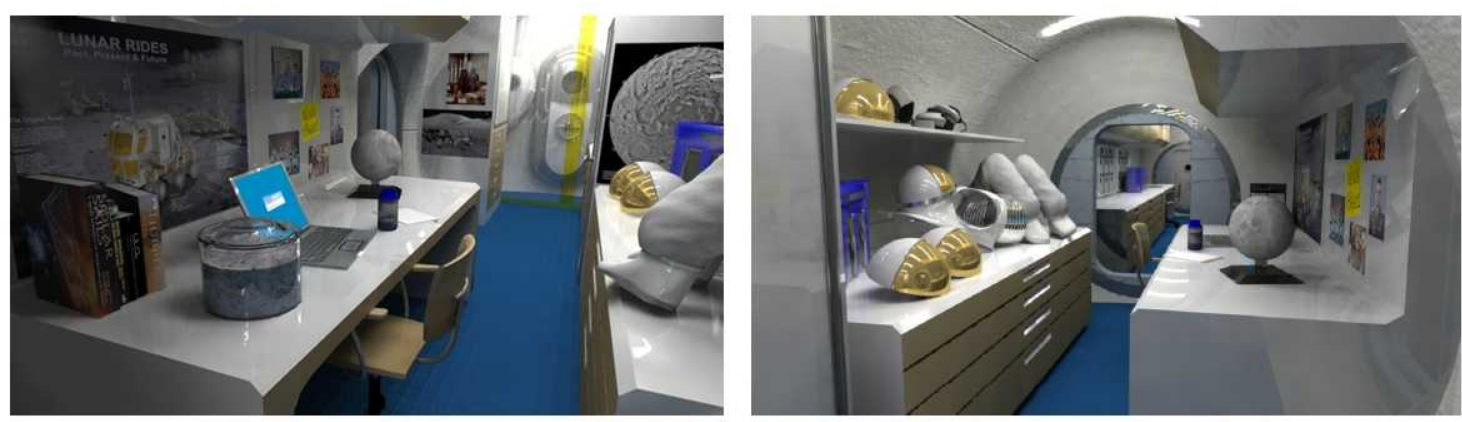

Figure 16, Suit Maintenance Area

The passive thermal Multi-Layered Insulation and Micrometeoroid / Secondary Ejecta protection system covers the Habitat hard shell structure. The SPE radiation protection of the crew is provided by a water wall in the PEM and PCM. 
The long-term GCR protection is being analyzed and thus not provided in the concept at this time.

The Habitat elements have external hatches that are $101.6 \mathrm{~cm}$ wide $\mathrm{x} 152.5$ $\mathrm{cm}$ tall (40" x 60") and are pressure-assisted opening inward. Each port has a Marmon flange for commonality with the rover Active-Active Mating Mechanism.

The PCM Habitat element has the primary Power Management \& Distribution System (PMAD) that manages distribution of power to the PCM habitat subsystems and to the PEM and PLM elements. The PMAD interfaces with the external power system in the PSU. The power storage system is external to the habitat in the PSU. The PMAD in the PCM Habitat has two DC to DC converters, two power distribution units, two 50-switch power switching units, two portable equipment panels, and appropriate primary and secondary wiring.

The Habitat elements (3) have an Active Thermal Control System (ATCS) and a Passive Thermal Control System (PTCS). The ATCS is the primary system for dissipating the thermal loads from the habitat element. The ATCS gathers the thermal load from within the habitat and passes this load to the external ATCS, a body-mounted $\sim 18 \mathrm{~m}^{2}$ radiator panel placed on top of the element. The Passive Thermal Control System (PTCS) reduces the thermal load in the habitat element by use of multi-layered insulation (MLI). The ATCS is designed to support the thermal loads and for the polar location environment. It has primary and secondary fluid loops using a 60/40 mixture of propylene glycol/water with stainless steel lines. The hardware is a mixture of Exploration Technology Development Program (ETDP) and ISS Thermal Control System (TCS) heritage. The Habitat element power and thermal loads are presented in Table 2 .

There is a partially closed-loop Life Support System in the PCM Habitat that also supports the minimal-capability Life Support Systems in the PEM and the PLM. The PCM Habitat provides the primary life support capability via the pressure control system, air revitalization, water recovery and management, waste management, fire detection and suppression, and emergency equipment. Air revitalization includes $\mathrm{CO} 2$ removal and reduction, $\mathrm{O} 2$ generation, trace contaminant control, ventilation and fans, airborne particulate control and monitoring, and atmosphere composition monitoring. The water recovery system includes H20 recovery of humidity condensate, waste hygiene and urine storage and distribution, and quality monitoring. The waste management system includes the urine collection and pre-treat, fecal collection, and trash collection. The waste and hygiene unit is located within the PCM Habitat near the water recovery system.

The avionics (communication, control, and data management) subsystem has strong commonality with the Altair Lander avionics. A wireless communications system is used throughout the habitation complex. The habitat avionics re-use the Lander avionics Common Service Assembly after landing. It will be relocated to the PCM Habitat / PSU post-landing and will provide the primary operating computers and communications system (including antennas). The PCM Habitat avionics subsystem has two crew utility panels, the EVA suitlock interface panel, two 
workstations, the network server, networking bus cabling and interface. The Lander avionics assembly includes two S-band software-defined radios, two operational computers, two bus interface units, antenna electronics, three Redundancy Management Units (RMUs), and a data recorder.

Outfitting is provided within the habitation element being delivered. Outfitting will be modular deployable furnishings based on the "Logistics-to-Living" concept of reusing Cargo Transfer Bags (CTB) to make internal furnishings. The PEM Habitat geoscience laboratory equipment will be stowed and will require deployment, setup and verification of operational status.

Crewmembers use individual sleep areas in the LERs during the initial outpost missions and in the final end-state Outpost. Privacy curtains provide visual privacy when crewmembers desire inside the LER.

A detailed Master Equipment List (MEL) documents the subsystem details and hardware selected for each habitat element. From this MEL a mass properties statement for the PCM Habitat is summarized in Table 3.

\section{Habitat Summary}

The power required (table 2) for nominal outpost operations is $\sim 9.4 \mathrm{~kW}$ (without a 30\% growth). The power required for the outpost while crew is not onboard during a quiescent mode is $\sim 3.2 \mathrm{~kW}$. The thermal conditioning required for air-cooled and cold-plated cooling is $\sim 3.5 \mathrm{~kW}$ and $5.8 \mathrm{~kW}$ respectively. The mass properties are shown in table 3 . The outpost configuration total mass to the surface is $\sim 16,561 \mathrm{~kg}$ for the three outpost habitation units.

Table 2, LS-12.0 Outpost Power \& Thermal Loads

\begin{tabular}{|c|c|c|c|c|}
\hline $\begin{array}{c}\text { Note: } \text { without the } \\
30 \% \text { growth }\end{array}$ & PCM & PEM & PLM & $\begin{array}{c}\text { Total Power \& } \\
\text { Thermal, W }\end{array}$ \\
\hline $\begin{array}{c}\text { Outpost Power } \\
\text { Active, We }\end{array}$ & 6992 & 1471 & 1018 & 9481 \\
\hline $\begin{array}{c}\text { Outpost Quiescent } \\
\text { Power, We }\end{array}$ & 1017 & 1207 & 1006 & 3230 \\
\hline $\begin{array}{c}\text { Outpost Air-Cooled } \\
\text { Thermal, } \mathrm{W}_{\mathrm{t}}\end{array}$ & 2756 & 454 & 261 & 3471 \\
\hline $\begin{array}{c}\text { Outpost Cold-Plated } \\
\text { Thermal, } \mathrm{W}_{\mathrm{t}}\end{array}$ & 4237 & 817 & 757 & 5811 \\
\hline
\end{tabular}


Table 3, LS-12.0 Outpost Habitation Elements Mass Properties

\begin{tabular}{|c|c|c|c|c|}
\hline $\begin{array}{c}\text { HABITAT } \\
\text { SUBSYSTEM }\end{array}$ & $\begin{array}{c}\text { PCM } \\
\text { mass, kg }\end{array}$ & $\begin{array}{c}\text { PEM } \\
\text { mass, kg }\end{array}$ & $\begin{array}{c}\text { PLM } \\
\text { mass, kg }\end{array}$ & $\begin{array}{c}\text { TOTAL } \\
\text { OUTPOST } \\
\text { MASS, kg }\end{array}$ \\
\hline Structures & 1863 & 1824 & 1324 & 5011 \\
\hline Protection & 563 & 563 & 202 & 1328 \\
\hline PM\&D & 319 & 314 & 314 & 947 \\
\hline ATCS & 346 & 159 & 135 & 640 \\
\hline Avionics ${ }^{1}$ & 125 & 46 & 43 & 214 \\
\hline Life Support & 1730 & 333 & 123 & 2186 \\
\hline EVA/Suitport & 0 & 408 & 0 & 408 \\
\hline Outfitting & 948 & 661 & 397 & 2006 \\
\hline Total Dry Mass & 5894 & 4308 & 2538 & 12740 \\
\hline 30\% Growth & 1768 & 1292 & 761 & 3821 \\
\hline Total Mass w/ & 7662 & 5600 & 3299 & 16561 \\
\hline 30\% & & & & \\
\hline
\end{tabular}

Note 1: Avionics reuses the Altair Lander Avionics Common Service Assembly; thus, the mass is not book kept here.

\section{Comparison of Lunar Scenario 12.0 and 12.1}

A comparison of the Lunar Scenarios 12.0 and 12.1 functionality and habitation configuration was performed to evaluate how common habitation requirements were met across the two configurations (horizontal and vertical) and to identify primary differences between the two approaches. Common with LS-12.0, LS-12.1 had a PCM, a PEM, and a PLM; each element was a $5.0 \mathrm{~m}$ inner diameter $\mathrm{x}$ $3.3 \mathrm{~m}$ inner height vertical cylinder and each provided $\sim 56 \mathrm{~m}^{3}$ pressurized volume and $\sim 20 \mathrm{~m}^{2}$ of floor area. An inflatable airlock (having $9 \mathrm{~m}^{3}$ pressurized volume) was attached to the PEM and four LERs (each having $\sim 12 \mathrm{~m}^{3}$ pressurized volume) provided a total of $226 \mathrm{~m}^{3}$ pressurized volume in the outpost configuration. For reference and comparison, the LS-12.1 outpost configuration is shown in figure 17. 


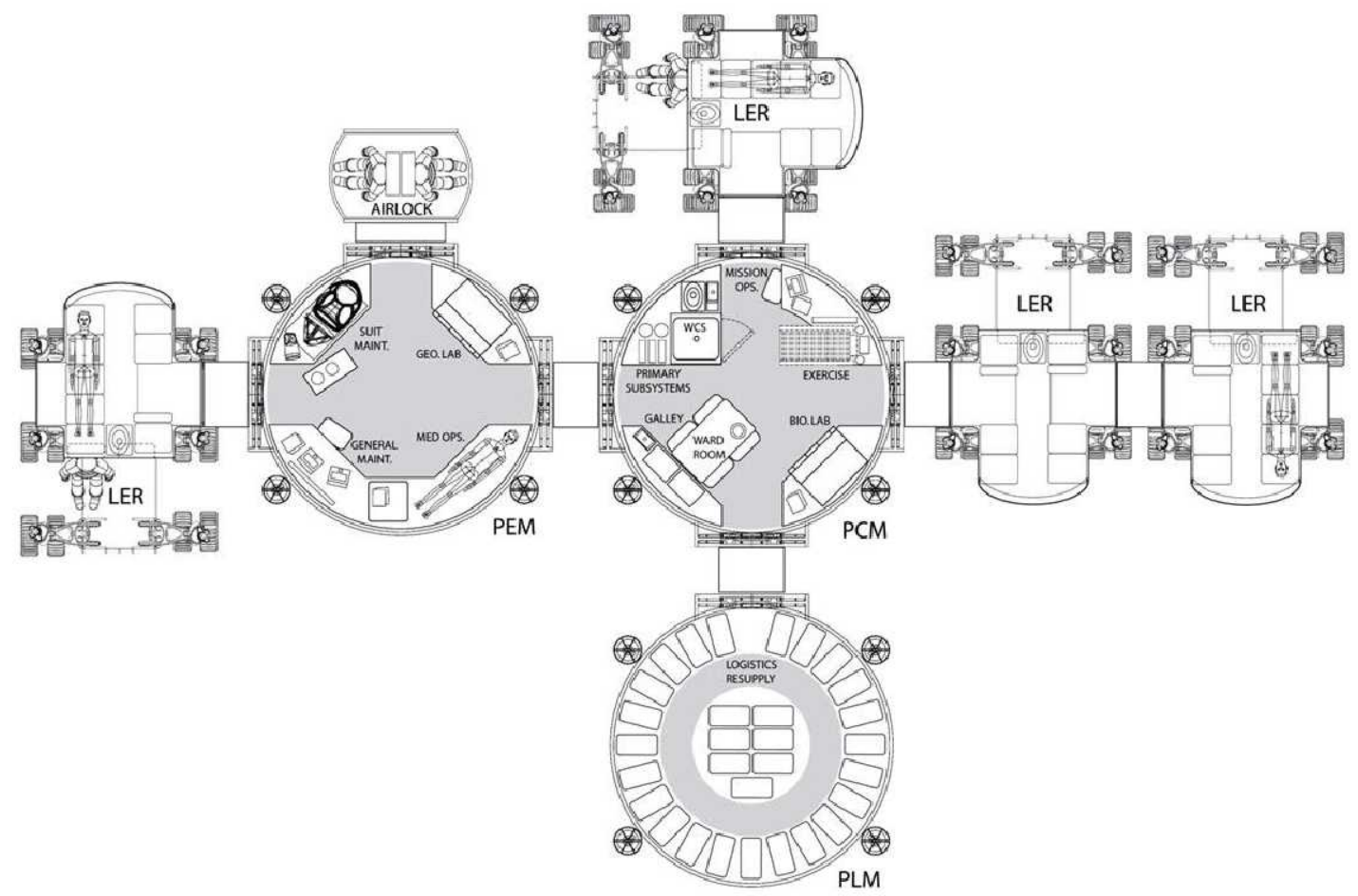

Figure 17, LS-12.1 Outpost Habitation Configuration

A common set of habitation function requirements was levied on both configurations and a summary functionality comparison is given in table 4. Both LS12.0 and LS-12.1 configurations met all of the required habitation functions. However, some differences were found in the partitioning and placement of these functions. For example, in LS-12.0, the medical operations, bioscience, and exercise facilities were co-located in the PCM, while in the LS-12.1 configuration, the medical operations function was placed in the PEM (for use during excursions) and the bioscience and exercise functions were co-located in the PCM. One of the biggest functionality differences was with regard to the airlock supporting the EVA function: in LS-12.0, the airlock/suitlock was integrated within the PEM habitat element, while an inflatable airlock attached to the PEM was used in LS-12.1 (both configurations assumed two-person suitports in each of the LERs, adding additional EVA capability). In addition, the two configurations used somewhat different approaches to radiation protection: the LS-12.0 configuration had integrated "water walls" in the PCM and PEM elements, while the LS-12.1 configuration used positioning of the consumables tankage above and below the PCM and PEM elements for shielding; both configurations used an "ice block" radiation shield in the LERs. 
Table 4, LS-12.0 and LS-12.1 Habitation Functions Comparison

\begin{tabular}{|c|c|c|}
\hline $\begin{array}{l}\text { HABITATION } \\
\text { FUNCTION }\end{array}$ & $\begin{array}{c}\text { LS } 12.0 \\
\text { HORIZONTAL } \\
\text { CONFIGURATION }\end{array}$ & $\begin{array}{c}\text { LS } 12.1 \\
\text { VERTICAL } \\
\text { CONFIGURATION }\end{array}$ \\
\hline Crew Quarters & $\begin{array}{c}4 \text { private crew quarters, isolatable } \\
\text { private areas, radiation shelter in } \\
\text { each LER }\end{array}$ & $\begin{array}{c}4 \text { private crew quarters, isolatable } \\
\text { private areas, radiation shelter in } \\
\text { each LER }\end{array}$ \\
\hline $\begin{array}{c}\text { Galley / } \\
\text { Meal Prep / } \\
\text { Crew Dining }\end{array}$ & $\begin{array}{l}1 \text { galley with food warmer, } \\
\text { group dining } \\
4 \text { "camper-type" meal prep } \\
\text { facilities in LERs } \\
\end{array}$ & $\begin{array}{l}1 \text { galley with food warmer, } \\
\text { group dining } \\
4 \text { "camper-type" meal prep } \\
\text { facilities in LERs } \\
\end{array}$ \\
\hline $\begin{array}{c}\text { Med/BioScience/Exercise } \\
\text { Facility }\end{array}$ & $\begin{array}{l}\text { Combined facility in PCM; } \\
\text { LERs have med kit }\end{array}$ & $\begin{array}{c}\text { Med Ops in PEM, exercise \& } \\
\text { Bio/Life Sciences in PCM; LERs } \\
\text { have med kit }\end{array}$ \\
\hline Geoscience Facility & $500 \mathrm{~kg}$ lab in PEM & $500 \mathrm{~kg}$ lab in PEM \\
\hline $\begin{array}{l}\text { Personal Hygiene } \\
\text { \&WCS }\end{array}$ & $\begin{array}{l}1 \text { wet-bath with sink, } 1 \text { WCS; } \\
\text { plumbing integrated into ECLSS; } \\
\text { LERs have reduced hygiene }\end{array}$ & $\begin{array}{l}1 \text { wet-bath with sink, } 1 \text { WCS; } \\
\text { plumbing integrated into ECLSS; } \\
\text { LERs have reduced hygiene }\end{array}$ \\
\hline $\begin{array}{l}\text { Airlock / } \\
\text { Suitlock / } \\
\text { Suitport }\end{array}$ & $\begin{array}{l}1 \text { hard-shell suitlock integrated in } \\
\text { PEM; } 2 \text { crew per ingress/egress; } \\
\quad 2 \text { suitports on each LER; } \\
\text { suit maintenance facility in PEM }\end{array}$ & $\begin{array}{l}1 \text { inflatable Airlock outside PEM; } \\
2 \text { crew per ingress/egress; } \\
2 \text { suitports on each LER; } \\
\text { suit maintenance facility in PEM }\end{array}$ \\
\hline Radiation shielding & $\begin{array}{c}\text { Water wall in PCM \& PEM; } \\
\text { LERs have "ice block" }\end{array}$ & $\begin{array}{l}\text { Tankage emplacement } \\
\text { LERs have "ice block" }\end{array}$ \\
\hline Advanced ECLSS & Yes in PCM & Yes in PCM \\
\hline Mobility & $\begin{array}{c}4 \text { LERs, used for mobility and } \\
\text { habitation }\end{array}$ & $\begin{array}{c}4 \text { LERs, used for mobility and } \\
\text { habitation }\end{array}$ \\
\hline $\begin{array}{c}\text { Logistics \& Stowage } \\
\text { Capability } \\
\text { (in Cargo Transfer Bag } \\
\text { Equivalents) } \\
\end{array}$ & $\begin{array}{l}\text { PCM: } 223 \\
\text { PEM: } 116 \\
\text { PLM: } 390\end{array}$ & $\begin{array}{l}\text { PCM: } 164 \\
\text { PEM: } 182 \\
\text { PLM: } 354\end{array}$ \\
\hline $\begin{array}{c}\text { Maintenance } \\
\text { (Suit \& General) }\end{array}$ & Facility in PEM & Facility in PEM \\
\hline
\end{tabular}

The two configurations were also compared with regard to a series of habitation system parameters; this comparison is summarized in table 5. As noted earlier, both configurations used the same number of habitat elements (PCM, PEM, PLM, 4 LERs); during concept development, element dimensions were chosen to create approximately equal interior pressurized volumes in the two outpost configurations while simultaneously meeting the lunar lander cargo delivery 
requirements. The total mass delivered for both outpost configurations was comparable, with the LS-12.1 configuration somewhat more massive. These mass differences came from a small number of differences in the two designs. For example, the LS-12.1 configuration had external structural supports and tankage above and below the habitat element, while the LS-12.0 horizontal elements had all structural support and tankage below the module. Additionally, the LS-12.0 PCM and PEM elements had radiation shielding (in the form of "water walls") integrated into the elements; this additional shielding was not present in the LS-12.1 habitat modules. The airlock/ suitlock functionality between the two configurations also contributed to mass differences: the LS-12.0 airlock/suitlock within the PEM was estimated at $\sim 408 \mathrm{~kg}$ while the mass of the inflatable airlock attached to the LS-12.1 PEM exterior was estimated at $\sim 738 \mathrm{~kg}$ (due to the requirement for significant internal structural support to the inflated shell). Also, the LS-12.1 PLM, having somewhat larger interior volume than the equivalent LS-12.1 PLM, could carry more pressurized consumables and, therefore, required more internal structural support, adding additional mass. Power requirements, interface connections, and pressure seals were all comparable between the two configurations.

Table 5, LS-12.0 and LS-12.1 Habitation System Parameters Comparison

\begin{tabular}{|c|c|c|}
\hline Parameter & $\begin{array}{c}\text { LS-12.0 } \\
\text { Horizontal Geometry }\end{array}$ & $\begin{array}{l}\text { LS-12.1 } \\
\text { Vertical Geometry }\end{array}$ \\
\hline \# of Elements & PCM, PEM, PLM, 4 LERs & PCM, PEM, PLM, 4 LERs \\
\hline $\begin{array}{c}\text { Total } \\
\text { Pressurized Volume } \\
\end{array}$ & $165+48=213 \mathrm{~m}^{3}$ & $\begin{array}{c}169.2+48=216 \mathrm{~m}^{3} \\
+9.0 \mathrm{~m}^{3} \text { Airlock }=226.2 \mathrm{~m}^{3} \\
\end{array}$ \\
\hline Total Floor Area & $\begin{array}{c}17.44 * 3=52 \mathrm{~m}^{2} \\
+4 \text { LERs }\end{array}$ & $\begin{array}{c}19.6 * 3=58.8 \mathrm{~m}^{2} \\
+4 \text { LERs }\end{array}$ \\
\hline $\begin{array}{l}\text { Total Habitation Mass } \\
\text { (incl. } 30 \% \text { growth) }\end{array}$ & $\begin{array}{c}22.1 \mathrm{mT} \\
(10444+8380+3299=22123)\end{array}$ & $\begin{array}{c}23.6 \mathrm{mT} \\
(10376+9178+3902=23456)\end{array}$ \\
\hline $\begin{array}{c}\text { Power }(\mathrm{kW}) \\
\text { (incl. } 30 \% \text { growth; } \\
\text { habitats only) }\end{array}$ & $\begin{array}{c}\text { Peak: } 12.3 \\
\text { Quiescent: } 4.2\end{array}$ & $\begin{array}{c}\text { Peak: } 12.7 \\
\text { Quiescent: } 4.2\end{array}$ \\
\hline $\begin{array}{c}\text { \# of Interface Connections } \\
\text { Required to Create Habitation } \\
\text { System } \\
\text { (Habitats Only) }\end{array}$ & 2 & 2 \\
\hline $\begin{array}{c}\text { Total \# of pressure seals / } \\
\text { hatches } \\
\text { (habitats only) }\end{array}$ & $\begin{array}{c}11 \\
\text { Habitats }=4+3+1=8 \\
\text { Suitports }=2 \\
\text { Hybrid Suitlock }=1 \text { (internal) }\end{array}$ & $\begin{array}{c}10 \\
\text { Habitats }=4+3+1=8 \\
\text { Suitports }=0 \\
\text { Airlock }=2\end{array}$ \\
\hline
\end{tabular}




\section{Summary of Lunar Scenario 12.0 Habitation}

This paper has provided an executive summary of the Lunar Scenario 12.0 habitation concepts defined during the Constellation Architecture Team-Lunar study. This study was performed by the multi-center LSS Habitation team of subject matter experts from April 2009 - July 2009 in preparation for the Constellation milestone of the Lunar Surface Concept Review. The concepts presented herein are not the final choice or baseline of a Lunar Scenario. Additional Lunar Scenarios will continue to be defined with International participation to drive out figures of merit, technical performance measures, desired features, functionality, operational concepts, risks, and cost considerations. Numerous Lunar Scenarios will be analyzed over the next nine months in preparation for the Constellation Lunar Surface Concept Review. Additional details of these CxAT-Lunar Scenarios can be found in the CXAT-Lunar Surface Architecture Reference Documents (SARD). During this CxAT-Lunar and LAT2 study cycle several surface habitat technologies were identified. A list of these needs have been integrated into the Constellation Technology Prioritization Process and to the Exploration Technology Development Program.

Considerations of how to protect the habitat from radiation with several meters of regolith, accessibility for maintenance, and repair need further definition. The ATHLETE heavy lifting mobile robotic system or the LSMS mitigates the risks associated with moving the habitat off the lander and ensuring the structural integrity of the pressure shell while it is being moved and emplaced at the outpost site location. When determining which habitation strategy to pursue, considerations of the mission objectives, risk, cost and safety of the crew are required. After which, each strategy should be traded-off to determine which approach best satisfies the requirements and performance challenges. Depending on the scenario objectives one or a combination of habitat strategies may be used or phased as the outpost matures.

\section{References}

1. NASA Space Flight Human System Standard Volume 1: Crew Health. NASASTD-3001, 03-05-2007. NASA, Washington, D.C. 20546-0001.

2. The Apollo Medical Operations Project: Recommendations to Improve Crew Health and Performance for Future Exploration Missions and Lunar Surface Operations. NASA/TM-2007-214755. August, 2007. NASA-Johnson Space Center, Houston, TX 77058.

3. Human System Integration Requirements Document, Constellation Program 70024, published 9/12/2006, NASA-Johnson Space Center, Houston, TX 77058

4. NASA's Exploration Systems Architecture Study, NASA, Nov. 2005

5. Constellation Architecture Requirements Document, CxP 70000 CARD, 2006

6. Constellation Design Reference Mission, CxP 00002, 2006

7. Constellation Program Systems Engineering Management Plan, CxP 70013 SEMP, 2006

8. Constellation Program Level 1 Operational Concept-draft, CxP 00004. 
9. A. Howe, G. Spexarth, L. Toups, R. Howard, M. Rudisill, J. Dorsey (2010). Constellation Architecture Team: Lunar Outpost Scenario 12.1 Habitation Concept. Proceedings of the Twelfth Biennial ASCE Aerospace Division International Conference on Engineering, Science, Construction, and Operations in Challenging Environments (Earth \& Space 2008); Honolulu, Hawaii, 14-17 March 2010. Reston, Virginia, USA: American Society of Civil Engineers. 